\title{
Exosomal Hsp70 in liquid biopsies - a biomarker for prediction and response monitoring in cancer
}

\author{
Caroline Werner ${ }^{1,2}$, Stefan Stangl 1,2, Lukas Salvermoser ${ }^{1,2}$, Melissa Schwab ${ }^{1,2}$, Maxim Shevtsov ${ }^{1,2,3}$, \\ Alexia Xanthopoulos ${ }^{1,2}$, Fei Wang1,2, Daniel Medenwald ${ }^{4}$, Martin Windberg ${ }^{4}$, Matthias Bache ${ }^{4}$, \\ Martin Schlapschy ${ }^{5}$, Arne Skerra ${ }^{5}$ and Gabriele Multhoff ${ }^{1,2, *}$
}

1 Center for Translational Cancer Research (TranslaTUM), Radiation Immuno-Oncology Group, Technical University of Munich (TUM), Klinikum rechts der Isar, Einsteinstr. 25, 81675 Munich, Germany;

2 Department of Radiation Oncology, Technical University of Munich (TUM), Klinikum rechts der Isar, Ismaningerstr. 22, 81675 Munich, Germany;

3 Institute of Cytology of the Russian Academy of Sciences (RAS), Tikhoretsky Ave. 4, 194064 St. Petersburg, Russia;

4 Department of Radiation Therapy, University Hospital Halle/Saale, Ernst-Grube Str. 40, 06120 Halle, Germany;

5 Lehrstuhl für Biologische Chemie, Technical University of Munich (TUM), School of Life Sciences, 85354 Freising, Germany

c.werner@tum.de, stefan.stangl@tum.de, lukas.salvermoser@gmx.de, melissa.schwab@tum.de, maxim.shevtsov@tum.de, $\quad$ alexia.x@gmx.at, feiwang@tum.de, daniel.medenwald@uk-halle.de, martin.windberg@student.uni-halle.de, matthias.bache@uk-halle.de; schlapschy@wzw.tum.de; skerra@tum.de

* Correspondence: gabriele.multhoff@tum.de; Tel.: + 4989 4140-4514

\begin{abstract}
In contrast to normal cells, tumor cells of multiple entities overexpress the Heat Shock Protein 70 (Hsp70) not only in the cytosol, but also present it on their plasma membrane in a tumor-specific manner. Furthermore, membrane-Hsp70 positive tumor cells actively release Hsp70 into lipid microvesicles termed exosomes into the blood. Due to conformational changes of Hsp70 in the lipid environment, most commercially available antibodies fail to detect membrane-bound and exosomal Hsp70. To fill this gap and to assess the role of exosomal Hsp70 in the circulation as a potential tumor biomarker, we established the novel complete Hsp70 (compHsp70) sandwich ELISA using two monoclonal antibodies (mAbs) that are able to recognize both, free and lipid-associated Hsp70 on the cell surface of viable tumor cells and exosomes. The epitopes of the mAbs cmHsp70.1 (aa 451-461) and cmHsp70.2 (aa 614-623) that are conserved among different species reside in the substrate-binding domain of Hsp70, with measured affinities of 0.42 $\mathrm{nM}$ and $0.44 \mathrm{nM}$, respectively. Validation of the compHsp70 ELISA revealed a high intra- and inter-assay precision, linearity in a concentration range of 1.56 to $25 \mathrm{ng} / \mathrm{ml}$, high recovery rates of 'spiked' liposomal Hsp70 (>84\%), comparable values between human serum and plasma samples, and no interference by food intake or age of the donors. Hsp70 concentrations in the circulation of patients with glioblastoma, squamous cell or adeno non-small cell lung carcinoma (NSCLC) at diagnosis were significantly higher than those of healthy volunteers. Hsp70 concentrations dropped concomitantly with the decrease in viable tumor mass on irradiation of patients with approximately $20 \mathrm{~Gy}$ (range $18-22.5 \mathrm{~Gy}$ ) or after completion of radiotherapy (60 - 70 Gy). In summary, the compHsp70 ELISA presented herein provides a highly sensitive and reliable tool for measuring free and exosomal Hsp70 in liquid biopsies of tumor patients, levels of which can be used as a predictive tumor-specific biomarker, risk assessment and for monitoring therapeutic outcome.
\end{abstract}

Keywords: Hsp70; sandwich ELISA; liquid biopsy; tumor biomarker; exosomes; prediction; response monitoring; non-small cell lung carcinoma (NSCLC); glioblastoma

\section{Introduction}

Lung cancer is the major cause of cancer-related deaths and the second most common cancer in men and women, worldwide [1]. Due to its nonspecific symptoms, lung cancer is frequently diagnosed at a late disease stage [2]. A relevant proportion of patients with locally advanced or metastasized tumors does not show an improvement in progression-free and overall survival following radical surgery, simultaneous chemo- and radiotherapy and immune checkpoint inhibitors [3,4]. Like NSCLC, 1 
glioblastoma multiforme (GBM) is a devastating disease of the central nervous system with symptoms that present at a very late disease stage. Despite multimodal treatment strategies consisting of surgery, radiotherapy and a temozolomide-based chemotherapy, overall survival remains poor at 15-18 months [5]. These examples underline the high medical need for tumor-specific biomarkers that improve the detection of tumors at an earlier stage and the monitoring of therapeutic responses. The development of such biomarkers will increase therapeutic success and the life expectancy of patients with highly aggressive tumors. Another challenge in clinical practice are the potential side effects of image-guided medical diagnosis. The availability of minimally invasive methods such as liquid biopsies for assessing the presence of tumor-specific biomarkers will have broad applicability and enable repetitive sampling with a good tolerability. Herein, we present an ELISA-based quantification of free and exosomal Hsp70 (HSPA1A) as a reliable approach for detecting tumors and monitoring therapeutic responses.

Members of the $70 \mathrm{kDa}$ chaperone family support folding of nascent polypeptides, prevent protein aggregation and assist transport of proteins across membranes [6,7], and they reside in nearly all subcellular compartments of nucleated cells [8]. The importance of Hsp70 is documented by its high abundance, evolutionary conserved amino acid (aa) sequence $[9,10]$ and functional similarities such as maintenance of protein homeostasis across different species [11]. Transgenic rodent models have revealed that Hsp70 of Drosophila melanogaster can substitute the activity of murine Hsp70 [12-14], and human Hsp70 expressed in myocardial cells of transgenic rats can protect the heart from ischemic stress, in vivo [15].

In contrast to normal cells, tumor cells frequently overexpress the major stress-inducible Hsp70 [16] in the cytosol and present it on the plasma membrane in a tumor-specific manner [17]. A global profiling of cell surface-bound proteins revealed a high abundancy of Hsp70 and other intracellular chaperones, like GRP78, GRP75, HSP60, HSP54, HSP27 on the plasma membrane of different tumor cells [18]. It is assumed that Hsp70 trafficking to the plasma membrane is enabled by an alternative nonER/Golgi endo-lysosomal pathway [19]. Since major changes in extracellular salt concentrations and $\mathrm{pH}$ fail to deplete Hsp70 from the plasma membrane, a (trans-) membrane receptor mediated anchorage of Hsp70 is highly unlikely. Lipid profiling and artificial lipid copellation assays revealed that Hsp70 can directly interact with glycosphingolipids such as globoyltriaosylceramide (Gb3) which localize in cholesterol-rich microdomains (rafts) in the membrane of tumor cells. Since normal cells lack this tumorspecific lipid composition in their plasma membrane, Hsp70 resides strictly in the cytosol of normal cells. Furthermore, stress triggers an interaction of Hsp70 with the apoptosis-related membrane lipid component phosphatidylserine (PS) [19].

An Hsp70 membrane positivity has been found in numerous different tumor entities [20], including lung, head and neck, colorectal, pancreas, breast carcinomas, and hematological malignancies [21,22]. Tumor cells presenting Hsp70 on their cell membrane are more resistant to radiotherapy and chemotherapy compared to their membrane-Hsp70 negative counterparts [23]. After exposure to environmental stress, the synthesis and membrane expression of Hsp70 is further upregulated in tumor cells. A high Hsp70 content contributes to an aggressive tumor phenotype, mediates protection against apoptosis, promotes invasion/migration and mediates resistance to standard therapies [24]. Moreover, viable tumor cells expressing Hsp70 on their plasma membrane actively release exosomes, whereas 'free' Hsp70 generally originates from dying cells [25-27]. Since exosomes are created by a double invagination, the protein content in exosomal membranes reflects that of the tumor cell membrane from which they originate [28]. As a result, membrane-Hsp70 positive tumor cells release exosomes presenting Hsp70 on their exosomal surface [27], and the lumen of exosomes contains proteins of the tumor cytosol [29]. 
We have previously shown that serum Hsp70 levels in patients with tumors are higher than in patients with infectious diseases [30] or healthy volunteers [31]. A high Hsp70 serum content correlates with an increased malignancy and resistance to chemo- and radiotherapy [22,32,33]. The precise detection of the viable tumor mass requires the measurement of exosomal Hsp70 which is actively released by viable tumor cells. Commercially available Hsp70 ELISA systems only detect free Hsp70 in aqueous solutions, but not exosomal Hsp70 in serum or plasma. The novel compHsp70 sandwich ELISA is based on two mAbs, cmHsp70.1 and cmHsp70.2 recognizing conserved epitopes in the C-terminal substrate binding domain of inducible Hsp70 [34,35] allows a specific and sensitive quantification of both, free and exosomal Hsp70 in the blood of patients with cancer.

\section{Materials and Methods}

\section{Recombinant Hsp70}

Human recombinant Hsp70 protein was produced in an optimized SF9 insect cell line (Orbigen, San Diego, CA, USA). Briefly, SF9 cells were transfected with baculovirus carrying the cDNA encoding human Hsp70 which was fused with an N-terminal poly-His tag (Orbigen, San Diego, CA, USA). After transfection, His-tagged Hsp70 was isolated from cell lysates by loading on a His-Trap nickel-sepharose column using an Äkta Purifier liquid chromatography system (GE Healthcare, Chalfont St. Giles, UK). His-tagged Hsp70 was eluted by increasing imidazole concentrations in a saline buffer (20 mM sodium phosphate, $0.5 \mathrm{M} \mathrm{NaCl}, 0.5 \mathrm{M}$ imidazole, $\mathrm{pH}$ 7.4) and pooled from different fractions. After subsequent desalting and rebuffering using PD-10 columns (GE Healthcare, Chalfont St. Giles, UK), the Hsp70 protein yield was determined using a BCA protein kit (Pierce, Thermo, Rockford, IL, USA). Hsp70 aliquots of $50 \mu \mathrm{g} / \mathrm{ml}$ were stored at $-80^{\circ} \mathrm{C}$.

\section{Microscale Thermophoresis-based affinity measurements}

Binding affinity of the rodent cmHsp70.1 and cmHsp70.2 monoclonal antibodies (mAbs) to Hsp70 protein was determined using the Microscale Thermophoresis (MST) technique [36,37]. For MST measurements, gradual thermophoretic changes of a constant concentration of FITC-labeled cmHsp70.1 and cmHsp70.2 mAbs (multimmune $\mathrm{GmbH}$, Munich, Germany) were incubated for 10 min with rising concentrations of recombinant Hsp70 protein (range $0.000148 \mathrm{nM}$ to $11.8 \mathrm{nM}$ ) and then analyzed on the Monolith NT.115 (NanoTemper Technologies GmbH, Munich, Germany).

\section{Western blot analysis}

Equal amounts of recombinant Hsp70 protein $(50 \mathrm{ng})$ were subjected to a SDS-PAGE, transferred to nitrocellulose membranes, blocked in 5\% w/v skimmed milk and incubated with the following Hsp70 antibodies (4.8 $\mu \mathrm{g} / \mathrm{ml}$, each): cmHsp70.1 (multimmune $\mathrm{GmbH}$, Munich, Germany), cmHsp70.2 (multimmune GmbH, Munich, Germany), hHSP70/HSPA1A Clone 998953 (R\&D Systems, Inc., MN, USA) and hHSP70/HSPA1A Clone 242707 (R\&D Systems, Inc., MN, USA). As secondary antibodies, horseradish-peroxidase (HRP)-conjugated anti-mouse (Dako P0260; 1:2000) and anti-rat (Dako P0450; 1:1000) antibodies were used.

\section{Peptide SPOT synthesis and analysis}

An array of consecutive 14-mer peptides with 12-residue overlap, covering the amino acid (aa) sequence 382-641 of human Hsp70, was synthesized according to the SPOT method, as previously described [38,39], on a Gly-PEG500-derivatised cellulose membrane using a MultiPep RS instrument (Intavis, Cologne, Germany). After N-terminal acetylation and de-protection of the peptide side chains, 
the membrane was treated with Membrane-Blocking Solution (MBS) containing 10\% v/v Western blocking reagent (Roche Diagnostics, Mannheim, Germany) and washed with MBS. After incubation with $5 \mu \mathrm{g} / \mathrm{ml} \mathrm{cmHsp} 70.2$ in MBS for $1 \mathrm{~h}$ at room temperature and washing with MBS, an incubation with a polyclonal Ig horseradish peroxidase conjugate, diluted 1:2000 in MBS, was performed, followed by a staining with 3,3'-diaminobenzidine.

\section{Cell culture}

The human lung carcinoma cell line A549 (adenocarcinoma alveolar basal epithelial cells, ATCC $®$ CCL-185 ${ }^{\mathrm{TM}}$ ) was cultured in RPMI1640 medium and the human colon carcinoma cell line HCT116 (ATCC ${ }^{\circledR}$ CCL-247 ${ }^{\mathrm{TM}}$ ) was cultured in Dulbecco's Modified Eagle's Medium (DMEM), both supplemented with $10 \%$ heat-inactivated fetal bovine serum (FBS), $2 \mathrm{mM} \mathrm{L-glutamine,} 1 \mathrm{mM}$ sodium pyruvate and antibiotics (100 IU/ml penicillin and $100 \mathrm{mg} / \mathrm{ml}$ streptomycin) and cultured at $37^{\circ} \mathrm{C}$ with $5 \% \mathrm{v} / \mathrm{v} \mathrm{CO} 2$ in a humidified atmosphere. Tumor cell lines were routinely monitored for mycoplasma contaminations (MycoAlert Mycoplasma Detection Kit, Lonza, Basel, Switzerland) and only mycoplasma-negative cells were used for analysis. All experiments were performed in the exponential growth phase on day 2 after seeding.

\section{Flow cytometry}

Cells $(300,000)$ were harvested, washed twice in ice cold flow cytometry buffer (phosphate buffered saline (PBS) containing 10\% v/v FBS) and incubated with the FITC-labeled cmHsp70.1, cmHsp70.2, hHSP70/HSPA1A Clone 998953 and hHSP70/HSPA1A Clone 242707 for $30 \mathrm{~min}$ in the dark on ice. Prior to acquisition, unbound antibody was removed by a second washing step. Propidium iodine (PI, Merck, Darmstadt, Germany) was added $(1 \mu \mathrm{g} / \mathrm{ml})$ directly before analysis and only viable (PI-negative) cells gated upon and analyzed on a FACSCalibur ${ }^{\mathrm{TM}}$ flow cytometer (BD Biosciences, Franklin Lakes, NJ, USA). Isotype-matched control antibodies were used as respective negative controls.

\section{Hsp70 containing artificial lipid vesicles}

Unilamellar artificial lipid microvesicles were freshly prepared for each experiment and used as 'model' exosomes. Briefly, 1-palmitoyl-2-oleoyl-sn-glycero-3-phosphocholine (POPC) and 1-palmitoyl2-oleoyl-sn-glycero-3-phospho-L-serine (POPS, both Avanti Polar Lipids, Alabaster, AL, USA), dissolved in chloroform, were mixed in a molar ratio of 8:2 and dried under a stream of nitrogen gas. Dried lipids were dissolved in $25 \mathrm{mM}$ Tris/ $\mathrm{HCl} \mathrm{pH} 7.4$ and $250 \mathrm{mM} \mathrm{NaCl}(1 \mathrm{ml} / 10 \mathrm{mg}$ of lipid) and incubated for $1.5 \mathrm{~h}$ at room temperature. The lipid suspension was forced through a lipid extruder (Avanti Polar Lipids, Alabaster, AL, USA) equipped with a $100 \mathrm{~nm}$ polycarbonate filter 15 times in order to generate unilamellar artificial liposomes (final concentration $1 \mathrm{mg} / \mathrm{ml}$ in $1 \mathrm{mM}$ Bis/Tris buffer, $\mathrm{pH}$ 7.4). Recombinant Hsp70 (1 mg/ml) was incubated with the lipid solution for $30 \mathrm{~min}$ at room temperature. After adding of ultrapure $\mathrm{H}_{2} \mathrm{O}, \mathrm{Hsp} 70$ containing lipids were ultra-centrifuged at 200,000 $\mathrm{g}$ at $4^{\circ} \mathrm{C}$ for $2 \mathrm{~h}$ and pellets were subsequently resuspended in PBS. Hsp70-containing and Hsp70-free control lipid vesicles were used within $24 \mathrm{~h}$ after preparation. The presence of Hsp70 protein in the pellet fraction, but not in the supernatant, confirmed binding of Hsp70 to lipid vesicles. The size and uniformity of the lipid vesicles were analyzed by dynamic light scattering (Zetasizer NanoS; Malvern Instruments, Malvern, UK).

\section{Collection of human plasma and serum samples}


Blood samples $(7.5 \mathrm{ml}$ each) were taken from healthy donors $(\mathrm{n}=108)$, and patients with non-small cell lung cancer (NSCLC; $\mathrm{n}=166$ ) and glioblastoma multiforme $(\mathrm{n}=34)$. Blood samples were also collected from patients with lung cancer at diagnosis $(n=80)$, during radiotherapy (after $20 \mathrm{~Gy} ; \mathrm{n}=58$ ) and after finishing radiotherapy (after $60-70 \mathrm{~Gy} ; \mathrm{n}=56$ ). All study participants provided informed, written consent. Approval of the study was obtained by the local ethical committees of the Klinikum rechts der Isar, Technical University of Munich and the University Hospital Halle a.d. Saale. Plasma was prepared from EDTA blood (S-Monovette, Sarstedt, Nümbrecht, Germany) by centrifugation at $1500 \mathrm{~g}$ for $15 \mathrm{~min}$ at room temperature. Serum was obtained after clotting of the blood for $30 \mathrm{~min}$ at room temperature in a serum separator tube with clotting activator (S-Monovette, Sarstedt, Nümbrecht, Germany), followed by centrifugation at $750 \mathrm{~g}$ for $10 \mathrm{~min}$. Serum and plasma were stored in aliquots $(150 \mu \mathrm{l})$ at $-80^{\circ} \mathrm{C}$. To test the influence of food intake as a potential interference factor, serum samples were collected from healthy human individuals before and $2 \mathrm{~h}$ after intake of a high fat diet.

\section{Biotinylation of the detection antibody}

The cmHsp70.1 monoclonal antibody and its corresponding control antibody, hHSP70/HSPA1A (Clone 242707), were biotinylated using EZ-link sulfo-NHS-LC-biotin (Thermo, Rockford, IL, USA). After adjustment of the carbonate-buffer to $\mathrm{pH} 8.5$, the antibody solution was incubated with a 40-fold molar excess of NHS-LC-biotin for $1 \mathrm{~h}$ at room temperature. The remaining free biotin was removed using Zeba spin desalting columns (Thermo Fisher Scientific, Waltham, MA, USA). Protein concentrations of the antibodies were determined using the BCA protein kit (Pierce, Thermo, Rockford, IL, USA) following the manufacturer`s recommendations.

\section{compHsp70 sandwich ELISA}

96-well MaxiSorp Nunc-Immuno plates (Thermo, Rochester, NY, USA) were coated overnight by incubating with $1 \mu \mathrm{g} / \mathrm{ml} \mathrm{cmHsp} 70.2$ (multimmune $\mathrm{GmbH}$, Munich, Germany) in sodium carbonate buffer (0.1 M sodium carbonate, $0.1 \mathrm{M}$ sodium hydrogen carbonate, $\mathrm{pH}$ 9.6). After washing with PBS (Life Technologies, Carlsbad, CA, USA) supplemented with 0.05\% Tween-20 (Calbiochem, Merck, Darmstadt, Germany), nonspecific binding was blocked by incubation with liquid plate sealer (Candor Bioscience $\mathrm{GmbH}$, Wangen i. Allgäu, Germany) for $30 \mathrm{~min}$ at room temperature. Following another washing step, serum or plasma samples diluted in StabilZyme Select Stabilizer (Diarect GmbH, Freiburg i. Breisgau, Germany), were added to the wells and incubated for $30 \mathrm{~min}$ at room temperature. An eightpoint concentration standard curve of Hsp70 protein $(0-100 \mathrm{ng} / \mathrm{ml})$ diluted in StabilZyme Select Stabilizer (Diarect $\mathrm{GmbH}$, Freiburg i. Breisgau, Germany) was included in each assay. After another washing step, wells were incubated with $200 \mathrm{ng} / \mathrm{ml}$ of the biotinylated cmHsp70.1 (multimmune $\mathrm{GmbH}$, Munich, Germany) in HRP-Protector (Candor Bioscience GmbH, Wangen i. Allgäu, Germany) for 30 $\mathrm{min}$ at room temperature. Following a final washing step, $57 \mathrm{ng} / \mathrm{ml}$ horseradish peroxidase (HRP)conjugated streptavidin (Senova $\mathrm{GmbH}$, Weimar, Germany), dissolved in HRP-Protector (Candor Bioscience $\mathrm{GmbH}$, Wangen i. Allgäu, Germany) was added for $30 \mathrm{~min}$ at room temperature. Colorimetric analysis was facilitated by adding a substrate reagent (BioFX TMB Super Sensitive One Component HRP Microwell Substrate, Surmodics, Inc., Eden Prairie, MN, USA) for $15 \mathrm{~min}$ at room temperature. The colorimetric reaction was stopped by adding $2 \mathrm{~N} \mathrm{H}_{2} \mathrm{SO}_{4}$ and absorbance read at 450 $\mathrm{nm}$, corrected by absorbance at $570 \mathrm{~nm}$, in a Microplate Reader (VICTOR X4 Multilabel Plate Reader, PerkinElmer, Waltham, MA, USA). As a control, soluble Hsp70 concentrations were measured using the DuoSet ${ }^{\circledR}$ IC Human/Mouse/Rat Total Hsp70 ELISA (R\&D Systems, Minneapolis, MN, USA) 
following the manufacturer's protocol. A comHsp70 ELISA kit is currently under development by DRG Instruments GmbH, Marburg, Germany.

Validation of the compHsp70 ELISA

To determine intra-assay precision, 36 different control sera were run twice on a 96 well ELISA plate. Inter-assay precision was assessed by running 39 serum samples in duplicates on three different 96 well ELISA plates. The concentration of each sample was determined, and the coefficient of variation (CV) was calculated using the ratio of standard deviation divided by the mean value. The Limit of Detection (LoD) was calculated in 42 blank samples and 42 samples with the lowest concentration of recombinant Hsp70 (1.56 ng/ml), as described by Armbruster \& Pry [40]. The Limit of Blank (LoB) was calculated according to the following equation: $\mathrm{LoB}=$ meanblank +1.645 (SDblank) and the Limit of Detection (LoD) was calculated according to the following equation: $\mathrm{LoD}=\mathrm{LoB}+1.645$ (SDlow concentration sample). Recombinant Hsp70 and Hsp70 in artificial lipid vesicles were measured in buffer and plasma of healthy donors. Recovery in plasma was assessed by spiking defined amounts of Hsp70 or Hsp70-containing vesicles in StabilZyme Select Stabilizer (Diarect GmbH, Freiburg i. Breisgau, Germany) into the plasma of healthy volunteers at a dilution of 1:5. The basal Hsp70 concentrations of the plasma into which the Hsp70 standards were spiked was subtracted from the values after spiking.

\section{Results}

\section{Epitope mapping of the cmHsp70.1 and cmHsp70.2 monoclonal antibodies (mAbs)}

Free Hsp70 in the circulation of tumor patients predominantly originates from dying cells, whereas exosomal Hsp70 is actively released by viable tumor cells. Currently available Hsp70 ELISA systems are unable to quantify the amount of exosomal Hsp70 in serum and plasma samples due to their inability to recognize an altered conformation of lipid-bound Hsp70. Consequently, we have established a novel compHsp70 sandwich ELISA which is based on the cmHsp70.1 and cmHsp70.2 mAbs. Epitope mapping of both antibodies using SPOT analysis $[34,38,39]$ revealed that the recognition sites of both antibodies are localized within the C-terminal substrate binding domain of Hsp70. The predominant linear sequences of the antibody epitopes of the cmHsp70.1 and cmHsp70.2 mAbs are N-L-L-G-R-F-EL-S-G (aa 454-461) [34] and A-G-G-P-G-P-G-G-F-G (aa 614-623, as determined in the present study), respectively.

A comparative inter-species analysis of the complete aa sequence of the major-stress inducible Hsp70 (HSPA1A) using the UniProt database in different species shows homologies of the human sequence with canine, rat, mouse and drosophila of $99 \%, 97 \%$ and $76 \%$, respectively. The 8 -mer epitope of the cmHsp70.1 mAb (aa 454-461; N-L-L-G-R-F-E-L) is 100\% identical in human, mouse, rat, dog, bovine, horse and pig, whereas a single aa exchange is present in the respective sequence of human Hsp70 (HSPA1A) and the highly homologous human Hsc70 (HSPA8) (aa 458; R to K). This aa exchange is also present in the HSPA1A epitope sequence of zebrafish. Since the sequence of feline HSPA1A is not available, human HSPA1A was compared to feline HSPA2 which shows two aa exchanges at positions 458 ( $\mathrm{R}$ to $\mathrm{K}$ ) and 460 ( $\mathrm{E}$ to $\mathrm{D}$ ). The inter-species similarities of the 10-mer sequence of the cmHsp70.2 mAb (aa 614-623; A-G-G-P-G-P-G-G-F-G) containing the antibody epitope was $100 \%$ conserved in human and pig, but there are 2 aa exchanges at positions 616 and 619 in human versus mouse and rat ( $\mathrm{G}$ to $\mathrm{A}$ and $\mathrm{P}$ to $\mathrm{A}$, respectively). The aa exchange at position 619 is also present in the relevant Hsp70 sequence of dog, bovine and horse. The 10-mer sequence of human HSPA1A differs in 3 positions to that of feline HSPA2 (aa 615, aa 620, aa 623) and in 5 positions in HSPA1A of human versus zebrafish (aa 614, aa 617, aa 618, aa 619, aa 622) (Table 1). All documented exchanges in the different 
species are conservative and nonpolar [41,42]. The epitope similarities of the cmHsp70.1 and Hsp70.2 mAbs indicates that, in addition to humans, the compHsp70 ELISA system is likely to be capable of measuring free and exosomal Hsp70 in the blood of different mammalian species, including dog, bovine, horse and pig.

Table 1. Inter-species comparison of the 8-mer (aa 454-461) and 10-mer (aa 614-623) sequences of Hsc70 (HSPA8) and Hsp70 (HSPA1A) in humans and different other species based on the UniProt database. The given sequences contain the epitopes of the cmHsp70.1 and cmHsp70.2 mAbs. $\left(^{*}\right)$ For feline Hsp70, only the aa sequence of HSPA2 is available. Amino acid (aa) exchanges are marked in grey.

\begin{tabular}{|c|c|c|c|c|}
\hline Species & $\begin{array}{c}\text { UniProt ID } \\
\text { Protein names }\end{array}$ & Total aa & $\begin{array}{c}\text { cmHsp70.1 (8-mer) } \\
\text { aa sequence }\end{array}$ & $\begin{array}{c}\text { cmHsp70.2 (10-mer) } \\
\text { aa sequence }\end{array}$ \\
\hline Human & $\begin{array}{c}\text { P11142 } \\
\text { HSPA8, Hsc70 }\end{array}$ & 646 & $\begin{array}{c}\text { N L L G K F E L } \\
454-461\end{array}$ & $\begin{array}{c}\text { A G G M P G G M P G } \\
614-623\end{array}$ \\
\hline Human & $\begin{array}{c}\text { P0DMV8 } \\
\text { HSPA1A, Hsp70 }\end{array}$ & 641 & $\begin{array}{c}\text { N L L G R F E L } \\
454-461\end{array}$ & $\begin{array}{c}\text { A G G P G P G G F G } \\
614-623 \\
\end{array}$ \\
\hline Mouse & $\begin{array}{c}\text { Q61696 } \\
\text { HSPA1A, Hsp70 } \\
\end{array}$ & 641 & $\begin{array}{c}\text { N L L G R F E L } \\
454-461 \\
\end{array}$ & $\begin{array}{c}\text { A G A P G A G G F G } \\
614-623 \\
\end{array}$ \\
\hline Rat & $\begin{array}{c}\text { P0DMW0 } \\
\text { HSPA1A, Hsp70 }\end{array}$ & 641 & $\begin{array}{c}\text { N L L G R F E L } \\
454-461\end{array}$ & $\begin{array}{c}\text { A G A P G A G G F G } \\
614-623\end{array}$ \\
\hline Dog & $\begin{array}{c}\text { Q7YQC6 } \\
\text { HSPA1A, Hsp70 } \\
\end{array}$ & 641 & $\begin{array}{c}\text { N L L G R F E L } \\
454-461 \\
\end{array}$ & $\begin{array}{c}\text { A G G P G A G G F G } \\
614-623 \\
\end{array}$ \\
\hline Bovine & $\begin{array}{c}\text { Q27975 } \\
\text { HSPA1A, Hsp70 }\end{array}$ & 641 & $\begin{array}{c}\text { N L L G R F E L } \\
454-461\end{array}$ & $\begin{array}{c}\text { A G G P G A G G F G } \\
614-623 \\
\end{array}$ \\
\hline Horse & $\begin{array}{c}\text { F7DW69 } \\
\text { HSPA1A, Hsp70 }\end{array}$ & 641 & $\begin{array}{c}\text { N L L G R F E L } \\
454-461\end{array}$ & $\begin{array}{c}\text { A G G P G A G G F G } \\
614-623 \\
\end{array}$ \\
\hline Pig & $\begin{array}{c}\text { P34930 } \\
\text { HSPA1A, Hsp70 }\end{array}$ & 641 & $\begin{array}{c}\text { N L L G R F E L } \\
454-461\end{array}$ & $\begin{array}{c}\text { A G G P G P G G F G } \\
614-623 \\
\end{array}$ \\
\hline Cat & $\begin{array}{c}\text { M3W8G1 } \\
\text { HSPA2* }{ }^{*}, \text { Hsp70.2 }\end{array}$ & 639 & $\begin{array}{c}\text { N L L G K F D L } \\
457-463 \\
\end{array}$ & $\begin{array}{c}\text { Q G G P G G G G S G } \\
615-624\end{array}$ \\
\hline Zebrafish & $\begin{array}{c}\text { B0S610 } \\
\text { HSPA1A, Hsp70 }\end{array}$ & 643 & $\begin{array}{c}\text { N L L G K F E L } \\
456-463\end{array}$ & $\begin{array}{c}\text { Q G G M P A G G C G } \\
614-623\end{array}$ \\
\hline
\end{tabular}

Binding affinities of cmHsp70.1 and cmHsp70.2 mAbs to recombinant Hsp70 protein

The $\mathrm{K}_{\mathrm{D}}$ values of the cmHsp70.1 and cmHsp70.2 mAbs to recombinant Hsp70 protein, as determined by Microscale Thermophoresis (MST) measurements, were $0.42 \mathrm{nM}$ and $0.44 \mathrm{nM}$, respectively (Figure 1a and 1b). 


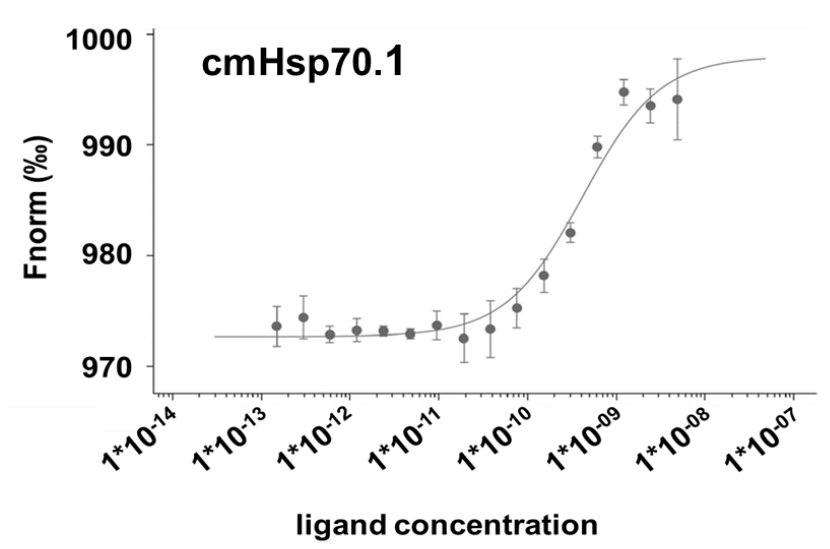

(a)

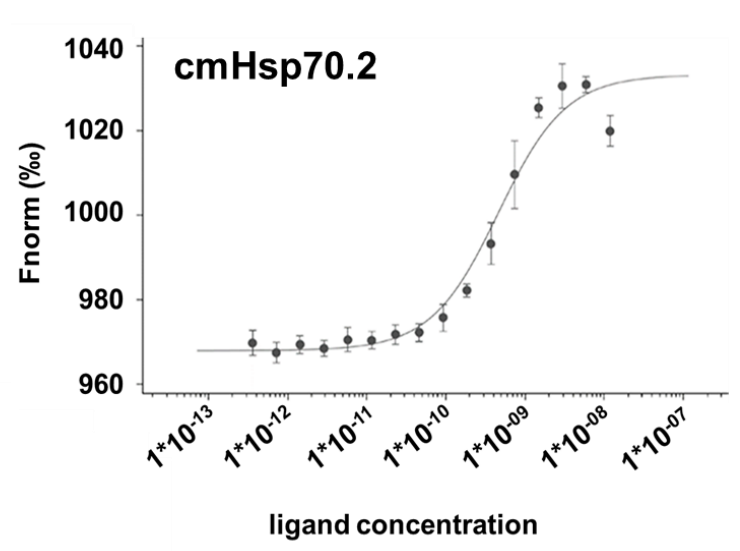

(b)

Figure 1. Binding affinity of the cmHsp70.1 and cmHsp70.2 mAbs. The binding affinity of cmHsp70.1 (KD $0.42 \mathrm{nM})(\mathrm{a})$ and $\mathrm{cmHsp} 70.2\left(\mathrm{~K}_{\mathrm{D}} 0.44 \mathrm{nM}\right)(\mathrm{b})$ to Hsp70 protein was measured using the Microscale Thermophoresis technique. The X-axis represents the concentration of the Hsp70 protein and the Fnorm (\%) is displayed on the Y-axis.

\section{Binding characteristics of Hsp70 antibodies to free and membrane-bound Hsp70 protein}

The binding characteristics of the cmHsp70.1 and cmHsp70.2 mAbs with respect to their capacity to detect free and lipid-bound Hsp70 were compared with those of two commercially available Hsp70 control antibodies (ctrl Hsp70A, ctrl Hsp70B) using Western blot and flow cytometric analysis of viable, membrane-positive tumor cells. As shown in Figure 2a, all tested antibodies detected recombinant Hsp70 protein $(50 \mathrm{ng}$ ) by Western blot analysis. To determine the capacity of the different Hsp70 antibodies to detect membrane-bound or liposomal Hsp70, flow cytometric analysis were performed using viable A549 (adenocarcinoma alveolar basal epithelial cells) and HCT116 (colon carcinoma) cells. For this, tumor cells were incubated with equal amounts of FITC labeled cmHsp70.1, cmHsp70.2, ctrl Hsp70A and ctrl Hsp70B antibodies; isotype-matched control antibodies were used as negative controls. As shown in Figure 2b, cmHsp70.1 and cmHsp70.2 mAbs specifically stained membrane-bound Hsp70 on the cell surface of viable (PI-negative) A549 and HCT116 tumor cells (87\% vs 94\% in A549 cells; $94 \%$ vs $98 \%$ in HCT116 cells, respectively). In contrast, the control antibodies (ctrl Hsp70A, ctrl Hsp70B) failed to detect membrane-bound Hsp70 on the cell surface of either tumor cell line.

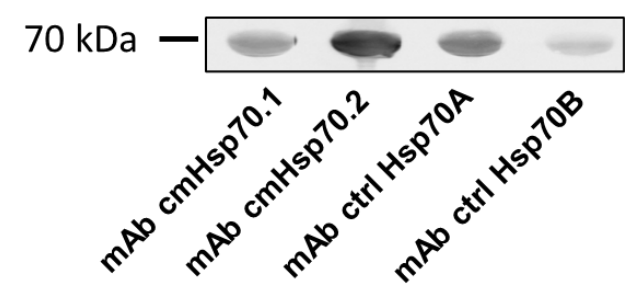

(a)

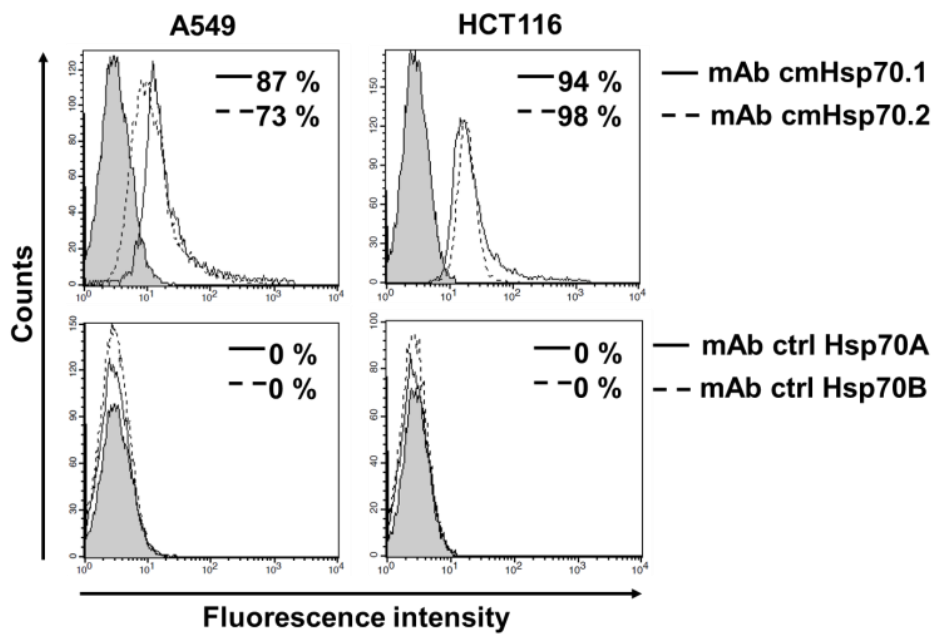

(b) 
Figure 2: Western blot and flow cytometric analysis of free and membrane-bound Hsp70 (a) Free Hsp70 protein, as determined in Western blot analysis using the cmHsp70.1, cmHsp70.2, ctrl Hsp70A and ctrl Hsp70B antibodies. (b) Detection of membrane-bound Hsp70 on A549 and HCT116 cell lines by flow cytometry using the cmHsp70.1, cmHsp70.2, ctrl Hsp70A and ctrl Hsp70B antibodies (white histograms). Staining with the respective isotype-matched control antibodies is represented by grey histograms. The numbers in the histograms indicate the proportion of Hsp70 positively stained cells.

Calibration curve and inter-and intra-assay precision of the compHsp70 ELISA using cmHsp70.1 and cmHsp70.2 $m A b s$

Since the cmHsp70.1 and cmHsp70.2 mAbs are able to bind both, free and membrane-bound, liposomal Hsp70, these antibodies were used to develop the compHsp70 sandwich ELISA. Comparative analysis revealed that cmHsp70.2 mAb qualifies best as the coating antibody and the cmHsp70.1 mAb as the detection antibody. An eight-point standard calibration curve (0 to $100 \mathrm{ng} / \mathrm{ml})$ was established using purified Hsp70 protein. A representative calibration curve, its regression equation, and the coefficient of determination ( $R^{2}$ value) are illustrated in Figure 3. In 42 independent ELISA experiments, the standard curve showed a high reproducibility with $R^{2}$ values ranging between 0.974 and 1.000 . The highest concentration of the standard $(100 \mathrm{ng} / \mathrm{ml})$ typically yielded a mean OD of $2.26 \pm 0.33$ Arbitrary Units (a.u.). The linearity of the compHsp70 ELISA remains stable within a concentration range of 1.56 $-25.00 \mathrm{ng} / \mathrm{ml}$.

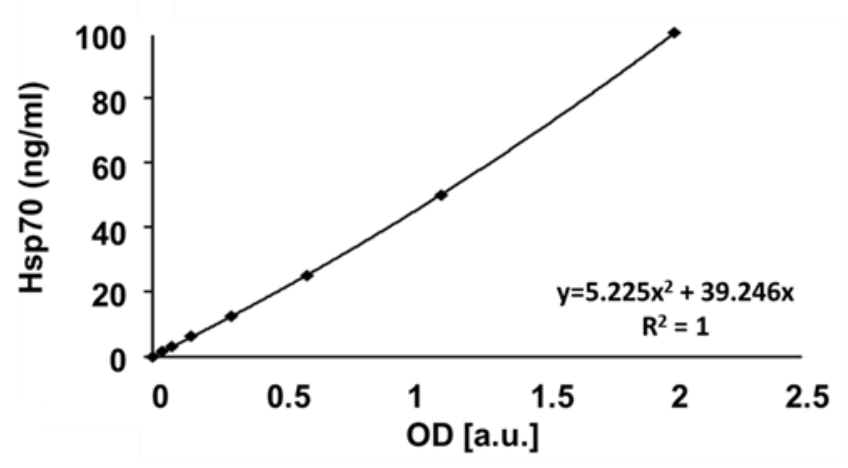

Figure 3: Representative eight-point calibration curve. The $X$-axis and $Y$-axis represent the OD (a.u.) and the Hsp70 protein concentration ( $\mathrm{ng} / \mathrm{ml})$, respectively.

The intra-assay precision coefficients of variation (CV) ranged between $0.02 \%$ and $12.50 \%$, as determined by analyzing 36 different serum samples in duplicate. The inter-assay precision coefficient (CV) varied between $0.38 \%$ and $7.34 \%$, as determined by analyzing 39 serum samples in duplicate in three independent ELISA experiments (Table 2).

Table 2. Assay performance of the compHsp70 ELISA.

\begin{tabular}{lll}
\hline Parameters & Performance & Mean values \\
\hline Linear range $(\mathrm{ng} / \mathrm{ml})$ & $1.56-25.00$ & \\
\hline Intra-assay precision $(\% \mathrm{CV})$ & $0.02-12.50$ & $3.82 \%$ \\
\hline $\begin{array}{l}\text { Inter-assay precision }(\% \mathrm{CV}) \\
\text { Recovery of Hsp70 }(\%)\end{array}$ & $0.38-7.34$ & $3.64 \%$ \\
buffer $(2.5 \mathrm{ng}) / \mathrm{plasma}(15 \mathrm{ng})$ & $105 \pm 1 / 92 \pm 9$ & \\
\hline Limit of Detection $(\mathrm{LoD}, \mathrm{ng} / \mathrm{ml})$ & 4.37 & \\
\hline
\end{tabular}


The recovery rates were determined after spiking different concentrations of recombinant Hsp70 protein into buffer and plasma samples of healthy volunteers. After spiking $2.5 \mathrm{ng} / \mathrm{ml} \mathrm{Hsp70} \mathrm{into} \mathrm{buffer,}$ the recovery rate by the compHsp70 ELISA was $105 \pm 1 \%$. After spiking $15 \mathrm{ng} / \mathrm{ml} \mathrm{Hsp70} \mathrm{into} \mathrm{plasma}$ samples, the recovery rate was $92 \pm 9 \%$. In the latter setting, the intrinsic Hsp70 content of the plasma sample was subtracted from the measured value. To further characterize the compHsp70 ELISA, the Limit of Detection (LoD), as calculated by using the equation $\mathrm{LoD}=\mathrm{LoB}+1.645$ (SDlow concentration sample), was determined to be $4.37 \mathrm{ng} / \mathrm{ml}$ (Table 2).

\section{Recovery of spiked liposomal Hsp70 using cmHsp70.1 and ctrl Hsp70A mAbs as detection antibodies}

To evaluate the capacity of cmHsp70.1 and ctrl Hsp70A mAbs to detect exosomal Hsp70 in the compHsp70 ELISA, artificially manufactured liposomes loaded with Hsp70 were prepared as artificial exosome surrogates. Hsp70-loaded artificial liposomes (liposomal Hsp70: $500 \mathrm{ng} / \mathrm{ml}$ ) were spiked into the serum of healthy volunteers and cmHsp70.2 mAb was used as a coating antibody in the ELISA. The recovery of liposomal Hsp70 using cmHsp70.1 and ctrl HSP70A mAbs as detection antibodies was 421.8 $\pm 34.6 \mathrm{ng} / \mathrm{ml}$ (black bar) and $113.2 \pm 6.6 \mathrm{ng} / \mathrm{ml}$ (grey bar), respectively (Figure 4a), which corresponds to recovery rates of $84.4 \pm 9.9 \%$ (black bar) and $22.7 \pm 1.3 \%$ (grey bar), respectively (Figure $4 \mathrm{~b}$ ). These data indicate that the recovery of lipid-bound Hsp70 by the cmHsp70.1 mAb was nearly 4-fold higher than that of the ctrl Hsp70A mAb when used as a detection antibody. The ctrl Hsp70B mAb was unable to detect any liposomal Hsp70 when used as a detection antibody in an identical experimental setting (data not shown). The ctrl Hsp70A and ctrl Hsp70B mAbs also did not function as effective coating antibodies in the compHsp70 ELISA (data not shown).

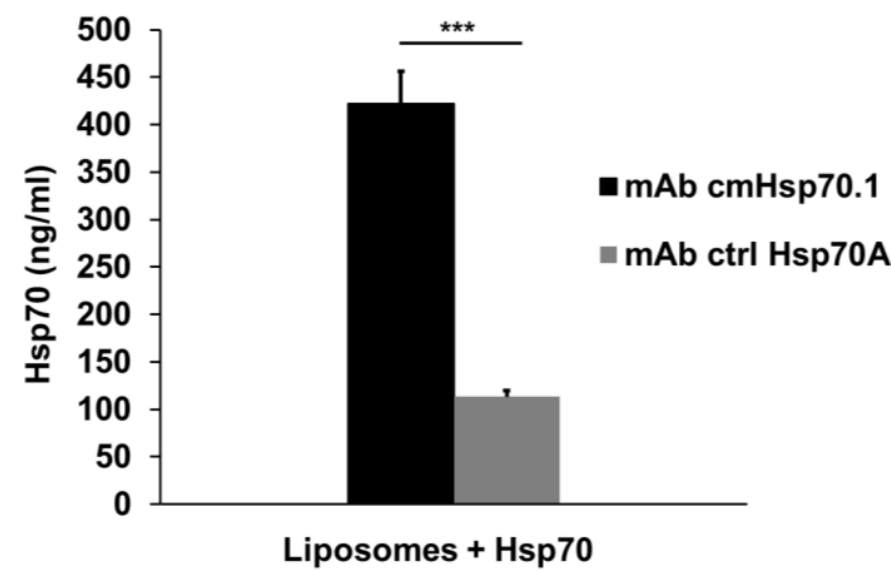

(a)

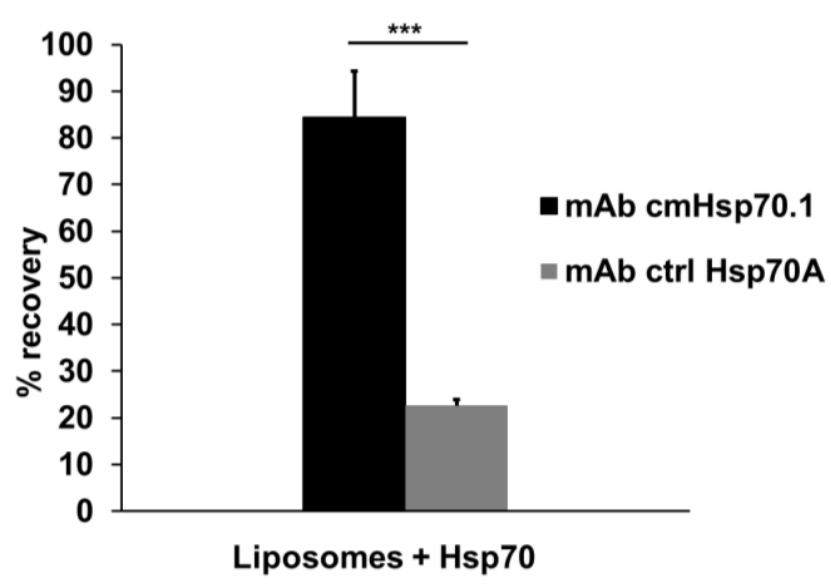

(b)

Figure 4. Detection and recovery of liposomal Hsp70 in serum. Quantification (a) and recovery (b) of lipid-bound Hsp70 in artificial lipid vesicles (liposomal Hsp70: $500 \mathrm{ng} / \mathrm{ml}$ ), as determined by the sandwich Hsp70 ELISA using the cmHsp70.2 mAb as a coating antibody, and cmHsp70.1 and ctrl Hsp70A mAbs as detection antibodies. The data represent mean values of three independent experiments.

Impact of interference factors on Hsp70 levels in the blood determined by the compHsp70 ELISA

To investigate the robustness of the data obtained with the compHsp70 ELISA using cmHsp70.2 $\mathrm{mAb}$ for coating and cmHsp70.1 mAb for detecting, serum and plasma samples from 13 healthy volunteers were collected. As shown in Figure 5a, Hsp70 concentrations measured in the plasma and serum by the compHsp70 ELISA were not significantly different. These data indicate that the 
compHsp70 ELISA can measure free and liposomal Hsp70 in both plasma and serum samples. To determine the influence of food intake on the detection of Hsp70 in the blood, serum samples were taken from 17 healthy individuals before and $2 \mathrm{~h}$ after an intake of a high fat diet. In all cases, serum Hsp70 concentrations before and after food intake were the same (Figure 5b). Since the age of the donors might have an impact on the Hsp70 concentrations in the circulation, plasma samples of 108 volunteers in different age groups ranging from 21-77 years (Table 3) were analyzed. As shown in Figure 5c, there was no significant correlation between plasma Hsp70 concentrations and the age of the donors, as determined using the Pearson correlation test $\left(\mathrm{R}^{2}=0.0781\right)$.

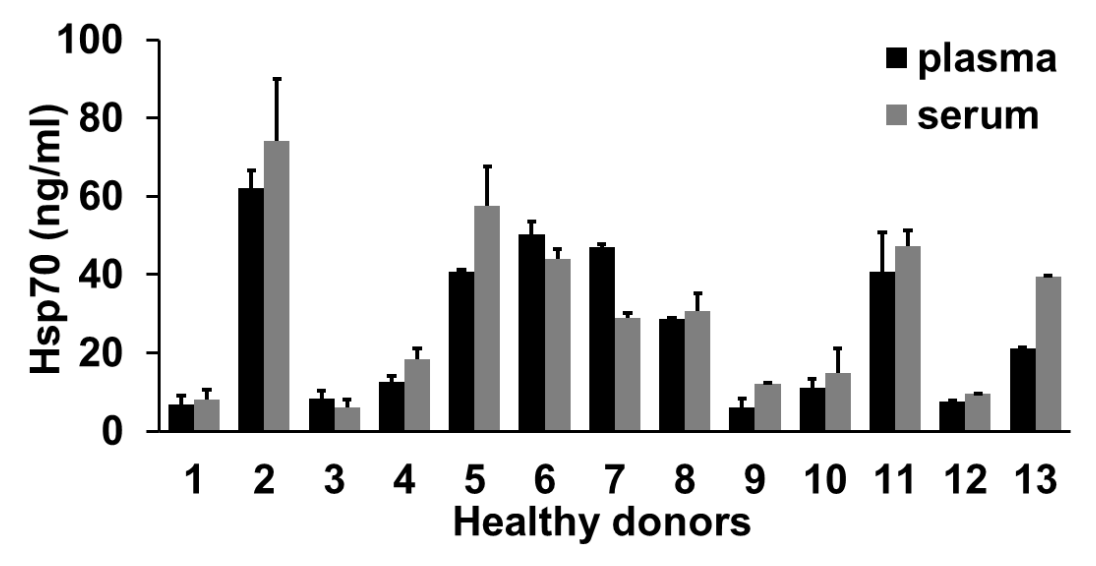

(a)

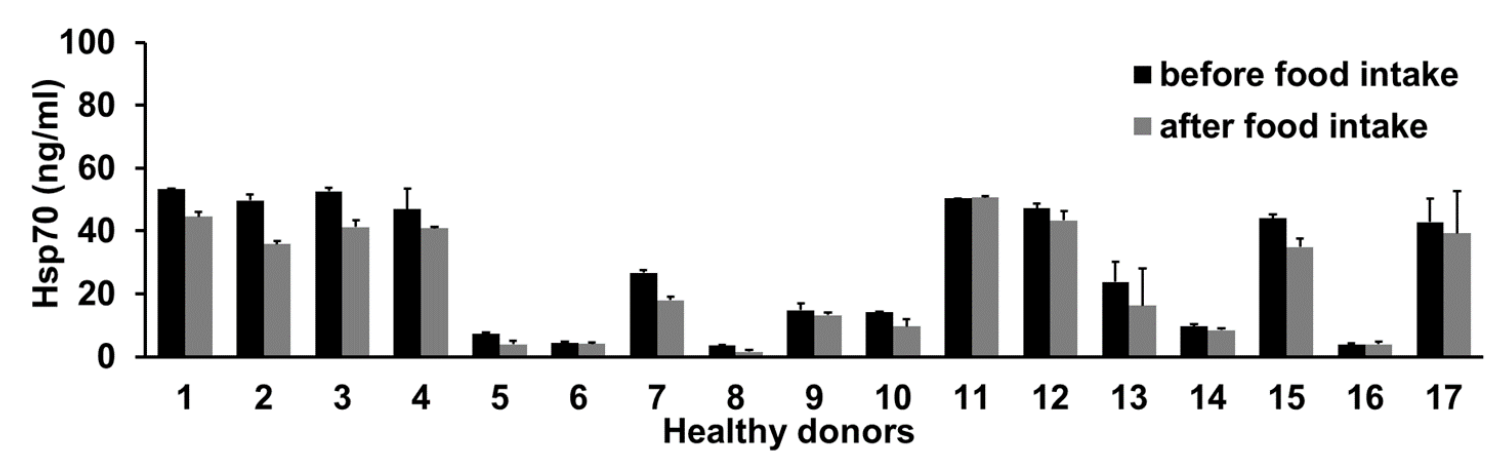

(b)

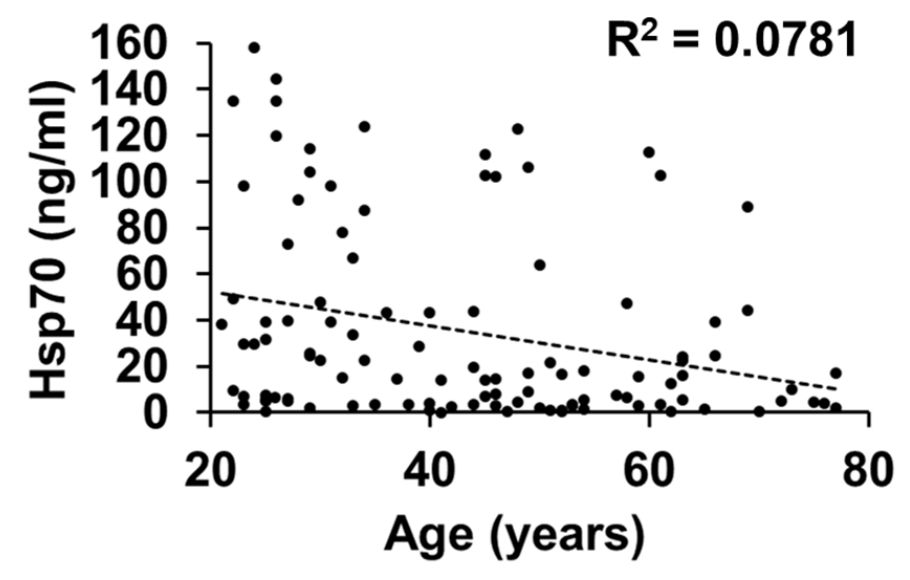

(c) 
Figure 5: Interference factors potentially influencing the Hsp70 concentrations measured by the compHsp70 ELISA. (a) Comparison of the Hsp70 concentrations in plasma and serum. Plasma (black bars) and serum (grey bars) from 13 healthy individuals were taken at the same time. (b) Hsp70 concentrations in the serum of 17 healthy individuals taken before (black bars) and $2 \mathrm{~h}$ after a high fat diet (grey bars). (c) Hsp70 concentration of 108 healthy volunteers in different age groups ranging from 21-77 years. Characteristics of the healthy donors are summarized in Table 3.

Comparative analysis of Hsp70 concentrations in the blood of cancer patients and healthy donors

In a first clinical evaluation, serum Hsp70 concentrations in patients with non-small cell lung carcinoma (NSCLC; $\mathrm{n}=166$ ) and high grade gliomas (HGG; $\mathrm{n}=34 ; 26$ primary, 8 relapse) were determined using the compHsp70 ELISA and compared to those in healthy volunteers $(n=108)$. The mean serum Hsp70 concentrations in patients with HGG (91.8 $\pm 21.3 \mathrm{ng} / \mathrm{ml})$ and NSCLC (332.2 \pm 37.9 $\mathrm{ng} / \mathrm{ml}$ ) were significantly higher than those in healthy volunteers (35.1 $\pm 4.0 \mathrm{ng} / \mathrm{ml}$; Figure 6a). Receiver Operating Characteristic (ROC) curve analysis compared serum Hsp70 concentrations of healthy individuals with those of NSCLC and HGG patients (Figure 6b). The Area Under the Curve (AUC), the CI 95\% value, the sensitivity and the specificity for a cut-off value was $114 \mathrm{ng} / \mathrm{ml}$ for NSCLC and $6 \mathrm{ng} / \mathrm{ml}$ for HGG patients, as determined by calculating the Youden-Index (Table 3).

Table 3. Characteristics and mean Hsp70 concentrations of healthy donors and patients with NSCLC and HGG. Used abbreviations in the Table: Area Under the Curve (AUC); Male (M); Female (F); Confidence Interval (CI); high grade glioma (HGG); Non-small cell lung cancer (NSCLC); Receiver Operating Characteristic (ROC); Standard Deviation (SD); Standard Error of the Mean (SEM).

\begin{tabular}{lllll}
\hline & & Healthy donors & NSCLC & HGG \\
\hline Number (n) & & 108 & 166 & 34 \\
\hline Gender (m/f) & & $51 / 57$ & $109 / 51$ & $28 / 6$ \\
\hline Age & Mean & 43 & 67 & 59 \\
\hline & Range & $21-77$ & $41-91$ & $21-84$ \\
\hline SD & 16 & 10 & 14 \\
\hline compHsp70 ELISA & Mean Hsp70 (ng/ml) & 35.06 & 67 & 60 \\
\hline ROC & SEM & 3.99 & 332.19 & 91.82 \\
\hline & AUC (Cl 95\%) & 37.90 & 21.28 \\
\hline & p-value & 0.88 & 0.62 \\
\hline Sensitivity (\%) & $<0.00001$ & 0.03 \\
\hline & Specificity (\%) & 68 & 91 \\
\hline & Threshold (ng/ml) & 94 & 33 \\
\hline
\end{tabular}

Patients with non-small cell lung carcinoma (NSCLC) were classified according to their histology (squamous cell carcinoma, adeno carcinoma) and tumor stage (stage I to IV). Mean Hsp70 concentrations were given in tumor subgroups containing more than 4 patients (Table 4 ). 
Table 4. Histology, tumor stage and mean Hsp70 values of squamous cell and adeno non-small cell lung cancer (NSCLC) patients. Data uncertainty is given as Standard Error of the Mean (SEM).

\begin{tabular}{llll}
\hline \multicolumn{1}{c}{ Histology } & Stage & $\begin{array}{l}\text { Number of cases } \\
\text { (n) }\end{array}$ & $\begin{array}{l}\text { Hsp70 } \\
\text { (ng/ml) }\end{array}$ \\
\hline Squamous cell carcinoma & I & 2 & \\
\hline Squamous cell carcinoma & II & 4 & $234.4 \pm 29.2$ \\
\hline Squamous cell carcinoma & III & 59 & $321.2 \pm 68.8$ \\
\hline Squamous cell carcinoma & IV & 12 & $249.9 \pm 64.4$ \\
\hline Squamous cell carcinoma & Not specified & 5 & \\
\hline Adeno carcinoma & I & 1 & $260.3 \pm 75.3$ \\
\hline Adeno carcinoma & II & 1 & $561.3 \pm 173.4$ \\
\hline Adeno carcinoma & III & 24 & $336.1 \pm 65.0$ \\
\hline Adeno carcinoma & IV & 29 & \\
\hline Adeno carcinoma & Not specified & 2 & \\
\hline Not otherwise specified & Not specified & 27 & \\
\hline
\end{tabular}

Compared to healthy individuals ( $35 \pm 3.99 \mathrm{ng} / \mathrm{ml} ; \mathrm{n}=108$ ), serum Hsp70 levels were significantly higher in patients with stage III and IV squamous cell carcinoma of the lung $(234.4 \pm 29.2 \mathrm{ng} / \mathrm{ml}$ and $321.2 \pm 68.8 \mathrm{ng} / \mathrm{ml}$, respectively) as well as in patients with stage III and IV adeno lung carcinoma (260.3 $\pm 75.3 \mathrm{ng} / \mathrm{ml}$ and $561.3 \pm 173.4 \mathrm{ng} / \mathrm{ml}$, respectively). For both tumor entities, Hsp70 concentrations were higher in patients with stage IV disease than those with stage III disease $\left({ }^{*} \mathrm{p}<0.05\right)$. Furthermore, Hsp70 concentrations were higher in patients with adeno than squamous cell carcinoma histology, although these differences did not reach statistical significance (Figure 6c).

In addition to measuring circulating Hsp70 concentrations in tumor patients at diagnosis, Hsp70 levels were determined in responding patients with NSCLC before, during and after completion of radiotherapy. For this, blood samples were collected from patients before radiotherapy, during radiotherapy (after approximately $20 \mathrm{~Gy}$; range $18-22.5 \mathrm{~Gy}$ ) and after completion of radiotherapy (60 - 70 Gy). Hsp70 concentrations before radiotherapy $(494.1 \pm 72.2 \mathrm{ng} / \mathrm{ml} ; \mathrm{n}=80)$, during radiotherapy $(310.5 \pm 36.8 \mathrm{ng} / \mathrm{ml} ; \mathrm{n}=58)$ and after completion of radiotherapy $(380.0 \pm 51.8 \mathrm{ng} / \mathrm{ml} ; \mathrm{n}=56)$ were significantly higher than those of healthy individuals $(35.1 \pm 3.99 \mathrm{ng} / \mathrm{ml} ; \mathrm{n}=108)$ when measured using the compHsp70 ELISA (Figure 6d). After receiving a radiation dose of approximately $20 \mathrm{~Gy}$ (range 18 $22.5 \mathrm{~Gy}$ ) Hsp70 levels dropped significantly from $494.1 \pm 72.2$ to $310.5 \pm 36.8 \mathrm{ng} / \mathrm{ml}$. After completion of radiotherapy (60 - 70 Gy) the Hsp70 concentration was $380.0 \pm 51.8 \mathrm{ng} / \mathrm{ml}$.

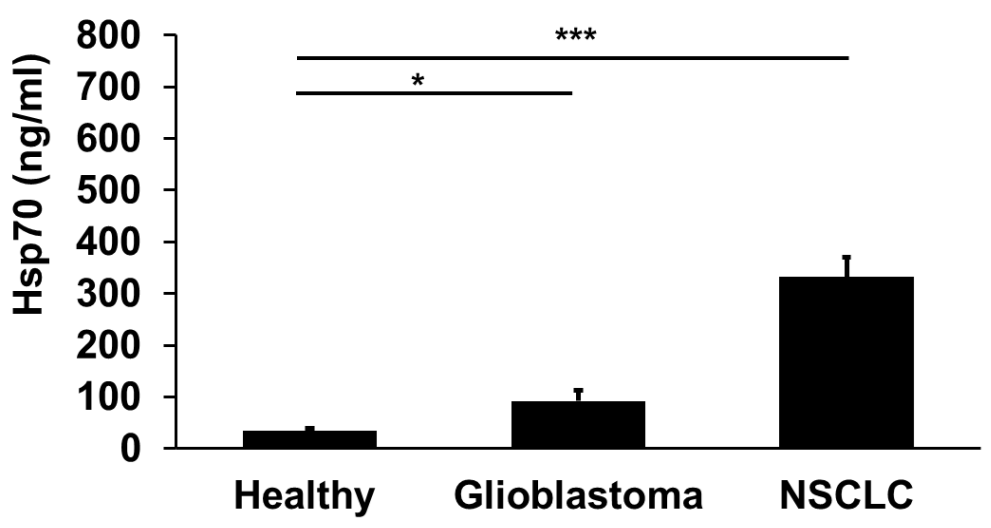

(a) 

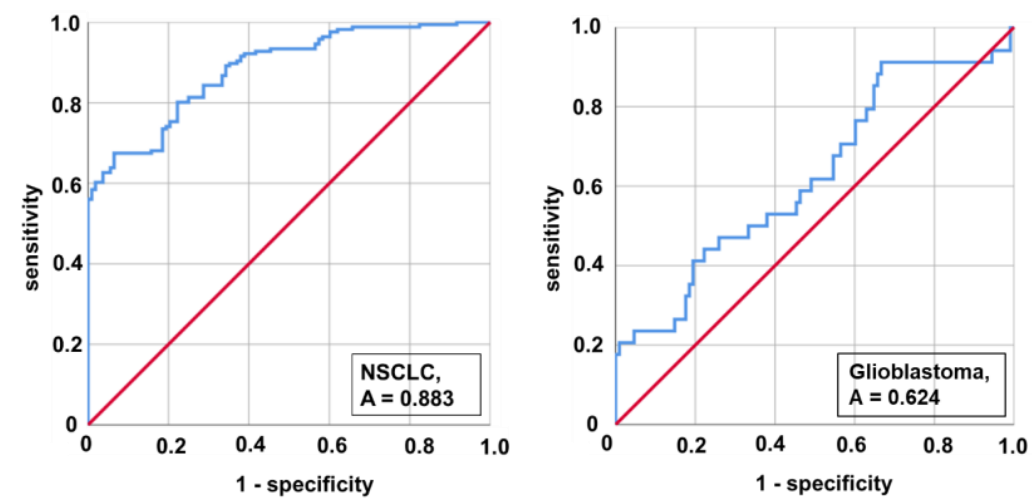

(b)

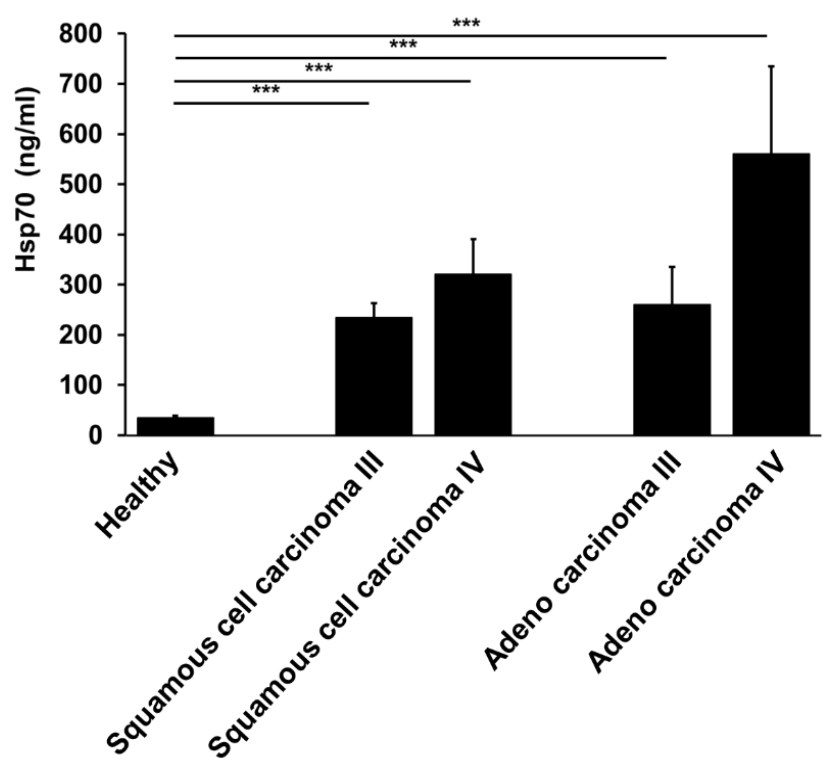

(c)

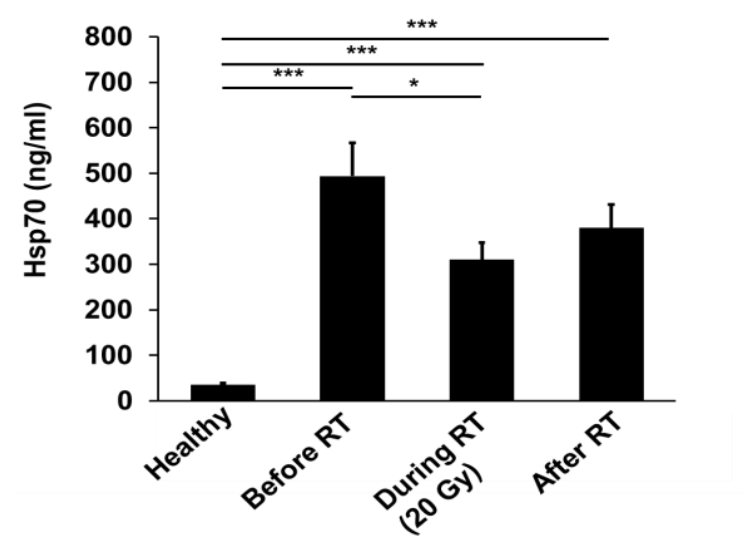

Figure 6. Serum Hsp70 concentrations in patients with different tumor entities. (a) Serum Hsp70 concentrations in healthy individuals $(n=108)$, patients with NSCLC $(n=166)$ and HGG $(n=34)$, as measured using the compHsp70 ELISA. Significantly higher Hsp70 levels were found in both tumor patient cohorts compared to healthy controls $\left({ }^{*} p<0.05,{ }^{* * *} p<0.001\right.$, Mann-Whitney U Test). (b) ROC curve analysis using the data shown in (a). (c) Serum Hsp70 concentrations in squamous cell carcinoma patients stage III $(234.4 \pm 29.2 \mathrm{ng} / \mathrm{ml} ; \mathrm{n}=59)$ and IV $(321.2 \pm 68.8 \mathrm{ng} / \mathrm{ml} ; \mathrm{n}=12)$ as well as adeno carcinoma patients stage III $(260.3 \pm 75.3 \mathrm{ng} / \mathrm{ml} ; \mathrm{n}=24)$ and IV $(561.3 \pm 173.4 \mathrm{ng} / \mathrm{ml}$; $\mathrm{n}=29)$ compared to Hsp70 levels of healthy individuals $(35.1 \pm 3.99 \mathrm{ng} / \mathrm{ml} ; \mathrm{n}=108)(\mathrm{p}<0.001$, t-test). Data uncertainty is given as Standard Error of the Mean (SEM). (d) Serum Hsp70 concentrations in patients before radiotherapy (Before RT; $494.1 \pm 72.2 \mathrm{ng} / \mathrm{ml} ; \mathrm{n}=80$ ), during radiotherapy (During $\mathrm{RT} ; 310.5 \pm 36.8 \mathrm{ng} / \mathrm{ml}$; after approximately $20 \mathrm{~Gy} ; \mathrm{n}=58$ ) and after radiotherapy (After RT; $380.0 \pm$ $51.8 \mathrm{ng} / \mathrm{ml} ; \mathrm{n}=56$ ), compared to healthy individuals (Healthy; $35.1 \pm 4.0 \mathrm{ng} / \mathrm{ml} ; \mathrm{n}=108$ ), as measured by the compHsp70 ELISA ( ${ }^{* * *} \mathrm{p}<0.001$, t-test). Following a dose of approximately $20 \mathrm{~Gy}$ (range $18-22.5 \mathrm{~Gy}$ ), the Hsp70 levels dropped significantly from $494.1 \pm 72.2$ to $310.5 \pm 36.8 \mathrm{ng} / \mathrm{ml}$ $\left({ }^{*} \mathrm{p}<0.05\right.$, t-test). 


\section{Discussion}

Liquid biomarkers detecting tumor-derived factors (e.g., proteins, exosomes and other extracellular vesicles, circulating tumor DNA, circulating tumor cells or circulating mRNAs) have the potential to improve tumor detection, diagnosis, prognosis, and the prediction of therapeutic responses $[43,44]$. Another advantage of liquid biopsies is the possibility of repeated sample collections using minimally invasive methods. Circulating biomarkers could provide clinically relevant information about the pathophysiology of the tumor, response to radio- and/or chemotherapies, and insight into the risk of developing metastatic disease and/or relapse, in real-time. Therefore, liquid biomarkers might enable a more accurate patient stratification and better tailored therapy decisions. Presently, only a few circulating protein-based biomarkers (e.g., cytokeratin CYFRA 21-1, CEA, CA125, neuron specific enolase (NSE), etc.) have been incorporated into clinical practice [45-49]. However, their use is often limited to certain tumor entities.

This study has established a novel compHsp70 sandwich ELISA which is based on two monoclonal antibodies that can detect both, free and liposomal Hsp70. Free Hsp70 predominantly origins from dying tumor cells, whereas lipid-bound, exosomal Hsp70 is actively released by a large variety of highly aggressive, membrane-Hsp70 positive viable tumor cells [27]. Exosomal Hsp70 might therefore be a valuable biomarker for determining the viable tumor mass at diagnosis and during or after therapy in different tumor entities. Most commercially available Hsp70 ELISA systems are validated only for the detection of free Hsp70 in aqueous solutions. The compHsp70 ELISA allows the quantification of tumorderived Hsp70 in serum and plasma with high precision and linearity in a clinically relevant concentration range. Sensitivity and specificity of the ELISA is documented by the fact that both ELISA antibodies only detect the major-stress inducible Hsp70 (HSPA1A) in different species. Despite a high inter species-specific homology, the epitopes of the two Hsp70 ELISA antibodies are not present in any other molecular chaperones such as Hsp40, Hsp60, Hsp90 (data not shown) or its highly homologous constitutively expressed family member, Hsc70 (HSPA8).

An impact of different factors such as lifestyle, age and gender on levels measured by the comHsp70 ELISA was excluded as the analysis of serum and plasma samples of 108 healthy individuals in different age groups, before and after intake of a high fat diet did not reveal any significant correlations.

Compared to healthy individuals, patients with late-stage squamous cell and adeno carcinoma of the lung and gliomas revealed significantly higher Hsp70 levels in the circulation at diagnosis. Since a major part of extracellular Hsp70 originates from exosomes and since the compHsp70 ELISA was shown to reliably detect spiked liposomal Hsp70 with a high sensitivity in the blood, it is very likely that elevated Hsp70 levels in the circulation of patients reflect the viable tumor mass. These data are in line with other studies reporting on elevated levels of chaperone-containing exosomes in tumor patients. Tumor exosomes mediate cytotoxic anti-cancer immune responses [50,51], increase tumor cell motility and growth [52,53], elicit tumor-specific immunity [54,55], promote angiogenesis [56] and transfer therapy resistance. In our study, significantly higher Hsp70 levels were detected in patients with latestage lung carcinoma $(\mathrm{p}<0.001)$ and glioblastoma $(\mathrm{p}<0.03)$ compared to healthy individuals. Moreover, the Hsp70 levels increase with higher tumor stages and thereby might serve as a biomarker for risk assessment. Subsequent receiver operating characteristic (ROC) curve analysis allowed a clear discrimination of Hsp70 serum levels in lung and brain cancer patients and healthy individuals. Given that, in addition to lung and brain tumors, membrane-Hsp70 is also present on the plasma membrane of a large variety of different other tumor types from which it is released into the extracellular milieu, it 
is reasonable to assume that extracellular Hsp70 might serve as a universal tumor biomarker in a broad range of cancer entities.

As previously reported [30,57], blood Hsp70 levels correlate with the intracellular Hsp70 levels and match the membrane-Hsp70 status of the tumor cells from which they originate. In this study, we observed a significant decrease in the extracellular Hsp70 levels in patients with lung carcinoma during (after approximately $20 \mathrm{~Gy}$ ) and after completion of radiotherapy (60 - $70 \mathrm{~Gy}$ ). In contrast, no significant drop in Hsp70 values was detected after radiotherapy when a commercial Hsp70 ELISA was used, and the values measured with the novel compHsp70 ELISA were more than 100-fold higher. The decrease in exosomal Hsp70 in the peripheral blood likely indicates a reduction in viable tumor mass in response to ionizing radiation. The minor, but not significant, increase of Hsp70 after completion of radiotherapy most likely attributes to an increased presence of free Hsp70 in the circulation derived from dying tumor cells and radiation-induced inflammation.

In line with our findings, a prospective clinical study including patients with solid tumors (breast and NSCLC) has also demonstrated exosomal Hsp70 levels to inversely correlate with therapeutic response [58]. In this study, a protocol that allows the isolation of exosomes from plasma samples of patients for a molecular characterization of lipid-bound proteins was established. However, the complexity and time-consuming nature of isolating exosomes limits its clinical application. The simultaneous evaluation of free and exosomal Hsp70 in serum and plasma of tumor patients using the compHsp70 ELISA might provide valuable and actionable clinical information for predicting therapeutic outcome in the future.

Herein, we demonstrate that exosomal Hsp70 levels qualify for estimating the clinical response to radiotherapy in lung carcinomas with adeno and squamous cell histologies. Since extracellular Hsp70 serves as a surrogate for the Hsp70 membrane status of the tumor, theranostic approaches [59] targeting membrane-Hsp70 positive tumors using antibodies, immune effector cells [60] and other approaches based on targeting membrane-Hsp70 could be based on the data derived with the compHsp70 ELISA. Despite promising results, longitudinal follow-up studies with different patient cohorts are necessary to fully evaluate and validate the clinical value of using the compHsp70 ELISA for monitoring tumor recurrence and metastasis and for the correlation of exosomal Hsp70 levels with progression-free survival (PFS) and overall survival (OS) in cancer patients.

The prognostic value can be further increased by combining the data on exosomal Hsp70 with that of other biomarkers in liquid biopsies such as circulating DNA and/or mircoRNA. This hypothesis is in line with a report of Tomita et al. which has shown that the combined monitoring of CYFRA 21-1 and CEA, as relevant biomarkers in patients with NSCLC, improves prognostic relevance [61].

In conclusion, the novel compHsp70 ELISA presented herein provides a reliable and robust tool to quantify free and liposomal Hsp70 in the serum and plasma of cancer patients, levels of which reflect the presence and risk characteristics of tumors, their membrane-Hsp70 status, and therapeutic response.

Funding: This research was funded by the DFG/SFB824, BMWi projects ZF4320102CS7 and ZF4320104AJ8 and the Hans-Böckler-Stiftung. M.S. was partly supported by RFBR, project № 19-08-00024

Conflict of Interest: Gabriele Multhoff declares a conflict of interest as a CSO of multimmune GmbH.

Acknowledgement: The authors want to thank Prof A. Graham Pockley for proof-reading of the English.

\section{References}

1. Siegel, R.L.; Miller, K.D.; Jemal, A. Cancer statistics, 2020. CA Cancer J Clin 2020, 70, 7-30, doi:10.3322/caac.21590. 
2. Guckenberger, M.; Allgauer, M.; Appold, S.; Dieckmann, K.; Ernst, I.; Ganswindt, U.; Holy, R.; Nestle, U.; Nevinny-Stickel, M.; Semrau, S., et al. Safety and efficacy of stereotactic body radiotherapy for stage 1 non-small-cell lung cancer in routine clinical practice: a patterns-ofcare and outcome analysis. J Thorac Oncol 2013, 8, 1050-1058, doi:10.1097/JTO.0b013e318293dc45.

3. Oberije, C.; De Ruysscher, D.; Houben, R.; van de Heuvel, M.; Uyterlinde, W.; Deasy, J.O.; Belderbos, J.; Dingemans, A.M.; Rimner, A.; Din, S., et al. A Validated Prediction Model for Overall Survival From Stage III Non-Small Cell Lung Cancer: Toward Survival Prediction for Individual Patients. Int J Radiat Oncol Biol Phys 2015, 92, 935-944, doi:10.1016/j.jirobp.2015.02.048.

4. Jung, C.Y.; Antonia, S.J. Tumor Immunology and Immune Checkpoint Inhibitors in Non-Small Cell Lung Cancer. Tuberc Respir Dis (Seoul) 2018, 81, 29-41, doi:10.4046/trd.2017.0120.

5. Stupp, R.; Mason, W.P.; van den Bent, M.J.; Weller, M.; Fisher, B.; Taphoorn, M.J.; Belanger, K.; Brandes, A.A.; Marosi, C.; Bogdahn, U., et al. Radiotherapy plus concomitant and adjuvant temozolomide for glioblastoma. N Engl J Med 2005, 352, 987-996, doi:10.1056/NEJMoa043330.

6. Hartl, F.U.; Hayer-Hartl, M. Molecular chaperones in the cytosol: from nascent chain to folded protein. Science 2002, 295, 1852-1858, doi:10.1126/science.1068408.

7. Lindquist, S.; Craig, E.A. The heat-shock proteins. Annu Rev Genet 1988, 22, 631-677, doi:10.1146/annurev.ge.22.120188.003215.

8. Schmitt, E.; Gehrmann, M.; Brunet, M.; Multhoff, G.; Garrido, C. Intracellular and extracellular functions of heat shock proteins: repercussions in cancer therapy. Journal of leukocyte biology 2007, 81, 15-27, doi:10.1189/jlb.0306167.

9. Lund, P.A. The roles of molecular chaperones in vivo. Essays Biochem 1995, 29, 113-123.

10. Hartl, F.U. Molecular chaperones in cellular protein folding. Nature 1996, 381, 571-579, doi:10.1038/381571a0.

11. Hunt, C.; Morimoto, R.I. Conserved features of eukaryotic hsp70 genes revealed by comparison with the nucleotide sequence of human hsp70. Proceedings of the National Academy of Sciences of the United States of America 1985, 82, 6455-6459, doi:10.1073/pnas.82.19.6455.

12. Mirault, M.E.; Southgate, R.; Delwart, E. Regulation of heat-shock genes: a DNA sequence upstream of Drosophila hsp70 genes is essential for their induction in monkey cells. EMBO J 1982, 1, 1279-1285.

13. Pelham, H.R. Hsp70 accelerates the recovery of nucleolar morphology after heat shock. EMBO J 1984, 3, 3095-3100.

14. Pelham, H.; Lewis, M.; Lindquist, S. Expression of a Drosophila heat shock protein in mammalian cells: transient association with nucleoli after heat shock. Philosophical transactions of the Royal Society of London. Series B, Biological sciences 1984, 307, 301-307, doi:10.1098/rstb.1984.0131.

15. Suzuki, K.; Sawa, Y.; Kaneda, Y.; Ichikawa, H.; Shirakura, R.; Matsuda, H. In vivo gene transfection with heat shock protein 70 enhances myocardial tolerance to ischemiareperfusion injury in rat. J Clin Invest 1997, 99, 1645-1650, doi:10.1172/JCI119327.

16. Jaattela, M. Escaping cell death: survival proteins in cancer. Exp Cell Res 1999, 248, 30-43, doi:10.1006/excr.1999.4455.

17. Multhoff, G.; Botzler, C.; Wiesnet, M.; Muller, E.; Meier, T.; Wilmanns, W.; Issels, R.D. A stressinducible 72-kDa heat-shock protein (HSP72) is expressed on the surface of human tumor cells, but not on normal cells. International journal of cancer 1995, 61, 272-279, doi:10.1002/ijc.2910610222.

18. Shin, B.K.; Wang, H.; Yim, A.M.; Le Naour, F.; Brichory, F.; Jang, J.H.; Zhao, R.; Puravs, E.; Tra, J.; Michael, C.W., et al. Global profiling of the cell surface proteome of cancer cells uncovers an abundance of proteins with chaperone function. J Biol Chem 2003, 278, 7607-7616, doi:10.1074/jbc.M210455200. 
19. Gehrmann, M.; Liebisch, G.; Schmitz, G.; Anderson, R.; Steinem, C.; De Maio, A.; Pockley, G.; Multhoff, G. Tumor-specific Hsp70 plasma membrane localization is enabled by the glycosphingolipid Gb3. PLoS One 2008, 3, e1925, doi:10.1371/journal.pone.0001925.

20. Calderwood, S.K.; Khaleque, M.A.; Sawyer, D.B.; Ciocca, D.R. Heat shock proteins in cancer: chaperones of tumorigenesis. Trends in biochemical sciences 2006, 31, 164-172, doi:10.1016/j.tibs.2006.01.006.

21. Hantschel, M.; Pfister, K.; Jordan, A.; Scholz, R.; Andreesen, R.; Schmitz, G.; Schmetzer, H.; Hiddemann, W.; Multhoff, G. Hsp70 plasma membrane expression on primary tumor biopsy material and bone marrow of leukemic patients. Cell stress \& chaperones 2000, 5, 438-442, doi:10.1379/1466-1268(2000)005<0438:hpmeop>2.0.co;2.

22. Pfister, K.; Radons, J.; Busch, R.; Tidball, J.G.; Pfeifer, M.; Freitag, L.; Feldmann, H.J.; Milani, V.; Issels, R.; Multhoff, G. Patient survival by Hsp70 membrane phenotype: association with different routes of metastasis. Cancer 2007, 110, 926-935, doi:10.1002/cncr.22864.

23. Murakami, N.; Kuhnel, A.; Schmid, T.E.; Ilicic, K.; Stangl, S.; Braun, I.S.; Gehrmann, M.; Molls, M.; Itami, J.; Multhoff, G. Role of membrane Hsp70 in radiation sensitivity of tumor cells. Radiat Oncol 2015, 10, 149, doi:10.1186/s13014-015-0461-1.

24. Ishaq, M.; Ojha, R.; Sharma, K.; Sharma, G.; Singh, S.K.; Majumdar, S. Functional inhibition of Hsp70 by Pifithrin-mu switches Gambogic acid induced caspase dependent cell death to caspase independent cell death in human bladder cancer cells. Biochim Biophys Acta 2016, 1863, 2560-2573, doi:10.1016/j.bbamcr.2016.07.001.

25. Vega, V.L.; Rodriguez-Silva, M.; Frey, T.; Gehrmann, M.; Diaz, J.C.; Steinem, C.; Multhoff, G.; Arispe, N.; De Maio, A. Hsp70 translocates into the plasma membrane after stress and is released into the extracellular environment in a membrane-associated form that activates macrophages. J Immunol 2008, 180, 4299-4307, doi:10.4049/jimmunol.180.6.4299.

26. Broquet, A.H.; Thomas, G.; Masliah, J.; Trugnan, G.; Bachelet, M. Expression of the molecular chaperone $\mathrm{Hsp} 70$ in detergent-resistant microdomains correlates with its membrane delivery and release. J Biol Chem 2003, 278, 21601-21606, doi:10.1074/jbc.M302326200.

27. Gastpar, R.; Gehrmann, M.; Bausero, M.A.; Asea, A.; Gross, C.; Schroeder, J.A.; Multhoff, G. Heat shock protein 70 surface-positive tumor exosomes stimulate migratory and cytolytic activity of natural killer cells. Cancer Res 2005, 65, 5238-5247, doi:10.1158/0008-5472.CAN04-3804.

28. Kharaziha, P.; Ceder, S.; Li, Q.; Panaretakis, T. Tumor cell-derived exosomes: a message in a bottle. Biochim Biophys Acta 2012, 1826, 103-111, doi:10.1016/j.bbcan.2012.03.006.

29. Mathivanan, S.; Ji, H.; Simpson, R.J. Exosomes: extracellular organelles important in intercellular communication. J Proteomics 2010, 73, 1907-1920, doi:10.1016/j.jprot.2010.06.006.

30. Gehrmann, M.; Cervello, M.; Montalto, G.; Cappello, F.; Gulino, A.; Knape, C.; Specht, H.M.; Multhoff, G. Heat shock protein 70 serum levels differ significantly in patients with chronic hepatitis, liver cirrhosis, and hepatocellular carcinoma. Front Immunol 2014, 5, 307, doi:10.3389/fimmu.2014.00307.

31. De Maio, A. Extracellular heat shock proteins, cellular export vesicles, and the Stress Observation System: a form of communication during injury, infection, and cell damage. It is never known how far a controversial finding will go! Dedicated to Ferruccio Ritossa. Cell stress \& chaperones 2011, 16, 235-249, doi:10.1007/s12192-010-0236-4.

32. Ciocca, D.R.; Calderwood, S.K. Heat shock proteins in cancer: diagnostic, prognostic, predictive, and treatment implications. Cell stress \& chaperones 2005, 10, 86-103, doi:10.1379/csc-99r.1.

33. Shevtsov, M.; Balogi, Z.; Khachatryan, W.; Gao, H.; Vigh, L.; Multhoff, G. Membrane-Associated Heat Shock Proteins in Oncology: From Basic Research to New Theranostic Targets. Cells 2020, 9, doi:10.3390/cells9051263.

34. Stangl, S.; Gehrmann, M.; Riegger, J.; Kuhs, K.; Riederer, I.; Sievert, W.; Hube, K.; Mocikat, R.; Dressel, R.; Kremmer, E., et al. Targeting membrane heat-shock protein 70 (Hsp70) on tumors 
by $\mathrm{cmHsp} 70.1$ antibody. Proceedings of the National Academy of Sciences of the United States of America 2011, 108, 733-738, doi:10.1073/pnas.1016065108.

35. Multhoff, G.; Hightower, L.E. Distinguishing integral and receptor-bound heat shock protein 70 (Hsp70) on the cell surface by Hsp70-specific antibodies. Cell stress \& chaperones 2011, 16, 251-255, doi:10.1007/s12192-010-0247-1.

36. Jerabek-Willemsen, M.; Wienken, C.J.; Braun, D.; Baaske, P.; Duhr, S. Molecular interaction studies using microscale thermophoresis. Assay Drug Dev Technol 2011, 9, 342-353, doi:10.1089/adt.2011.0380.

37. Wienken, C.J.; Baaske, P.; Rothbauer, U.; Braun, D.; Duhr, S. Protein-binding assays in biological liquids using microscale thermophoresis. Nat Commun 2010, 1, 100, doi:10.1038/ncomms1093.

38. Frank, R. The SPOT-synthesis technique. Synthetic peptide arrays on membrane supports-principles and applications. J Immunol Methods 2002, 267, 13-26, doi:10.1016/s00221759(02)00137-0.

39. Zander, H.; Reineke, U.; Schneider-Mergener, J.; Skerra, A. Epitope mapping of the neuronal growth inhibitor Nogo-A for the Nogo receptor and the cognate monoclonal antibody IN-1 by means of the SPOT technique. J Mol Recognit 2007, 20, 185-196, doi:10.1002/jmr.823.

40. Armbruster, D.A.; Pry, T. Limit of blank, limit of detection and limit of quantitation. Clin Biochem Rev 2008, 29 Suppl 1, S49-52.

41. Schaefer, C.; Rost, B. Predict impact of single amino acid change upon protein structure. $B M C$ Genomics 2012, 13 Supp/ 4, S4, doi:10.1186/1471-2164-13-S4-S4.

42. Lopez, M.J.; Mohiuddin, S.S. Biochemistry, Essential Amino Acids. In StatPearls, Treasure Island (FL), 2020.

43. Crosbie, P.A.; Shah, R.; Summers, Y.; Dive, C.; Blackhall, F. Prognostic and predictive biomarkers in early stage NSCLC: CTCs and serum/plasma markers. Transl Lung Cancer Res 2013, 2, 382397, doi:10.3978/j.issn.2218-6751.2013.09.02.

44. Rolfo, C.; Castiglia, M.; Hong, D.; Alessandro, R.; Mertens, I.; Baggerman, G.; Zwaenepoel, K.; Gil-Bazo, I.; Passiglia, F.; Carreca, A.P., et al. Liquid biopsies in lung cancer: the new ambrosia of researchers. Biochim Biophys Acta 2014, 1846, 539-546, doi:10.1016/j.bbcan.2014.10.001.

45. Kulpa, J.; Wojcik, E.; Reinfuss, M.; Kolodziejski, L. Carcinoembryonic antigen, squamous cell carcinoma antigen, CYFRA 21-1, and neuron-specific enolase in squamous cell lung cancer patients. Clin Chem 2002, 48, 1931-1937.

46. Pujol, J.L.; Boher, J.M.; Grenier, J.; Quantin, X. Cyfra 21-1, neuron specific enolase and prognosis of non-small cell lung cancer: prospective study in 621 patients. Lung Cancer 2001, 31, 221-231, doi:10.1016/s0169-5002(00)00186-0.

47. Kozu, Y.; Maniwa, T.; Takahashi, S.; Isaka, M.; Ohde, Y.; Nakajima, T. Prognostic significance of postoperative serum carcinoembryonic antigen levels in patients with completely resected pathological-stage I non-small cell lung cancer. J Cardiothorac Surg 2013, 8, 106, doi:10.1186/1749-8090-8-106.

48. Tomita, M.; Shimizu, T.; Ayabe, T.; Onitsuka, T. Maximum SUV on positron emission tomography and serum CEA level as prognostic factors after curative resection for non-small cell lung cancer. Asia Pac J Clin Oncol 2012, 8, 244-247, doi:10.1111/j.1743-7563.2012.01549.x.

49. Pujol, J.L.; Molinier, O.; Ebert, W.; Daures, J.P.; Barlesi, F.; Buccheri, G.; Paesmans, M.; Quoix, E.; Moro-Sibilot, D.; Szturmowicz, M., et al. CYFRA 21-1 is a prognostic determinant in nonsmall-cell lung cancer: results of a meta-analysis in 2063 patients. British journal of cancer 2004, 90, 2097-2105, doi:10.1038/sj.bjc.6601851.

50. Andre, F.; Schartz, N.E.; Movassagh, M.; Flament, C.; Pautier, P.; Morice, P.; Pomel, C.; Lhomme, C.; Escudier, B.; Le Chevalier, T., et al. Malignant effusions and immunogenic tumourderived exosomes. Lancet 2002, 360, 295-305, doi:10.1016/S0140-6736(02)09552-1.

51. Wyciszkiewicz, A.; Kalinowska-Lyszczarz, A.; Nowakowski, B.; Kazmierczak, K.; Osztynowicz, K.; Michalak, S. Expression of small heat shock proteins in exosomes from patients with gynecologic cancers. Scientific reports 2019, 9, 9817, doi:10.1038/s41598-019-46221-9. 
52. McCready, J.; Sims, J.D.; Chan, D.; Jay, D.G. Secretion of extracellular hsp90alpha via exosomes increases cancer cell motility: a role for plasminogen activation. BMC cancer 2010, 10, 294, doi:10.1186/1471-2407-10-294.

53. Li, X.; Wang, S.; Zhu, R.; Li, H.; Han, Q.; Zhao, R.C. Lung tumor exosomes induce a proinflammatory phenotype in mesenchymal stem cells via NFkappaB-TLR signaling pathway. $J$ Hematol Oncol 2016, 9, 42, doi:10.1186/s13045-016-0269-y.

54. Guo, D.; Chen, Y.; Wang, S.; Yu, L.; Shen, Y.; Zhong, H.; Yang, Y. Exosomes from heat-stressed tumour cells inhibit tumour growth by converting regulatory T cells to Th17 cells via IL-6. Immunology 2018, 154, 132-143, doi:10.1111/imm.12874.

55. Lv, L.H.; Wan, Y.L.; Lin, Y.; Zhang, W.; Yang, M.; Li, G.L.; Lin, H.M.; Shang, C.Z.; Chen, Y.J.; Min, J. Anticancer drugs cause release of exosomes with heat shock proteins from human hepatocellular carcinoma cells that elicit effective natural killer cell antitumor responses in vitro. J Biol Chem 2012, 287, 15874-15885, doi:10.1074/jbc.M112.340588.

56. Yukawa, H.; Suzuki, K.; Aoki, K.; Arimoto, T.; Yasui, T.; Kaji, N.; Ishikawa, T.; Ochiya, T.; Baba, Y. Imaging of angiogenesis of human umbilical vein endothelial cells by uptake of exosomes secreted from hepatocellular carcinoma cells. Scientific reports 2018, 8, 6765, doi:10.1038/s41598-018-24563-0.

57. Gunther, S.; Ostheimer, C.; Stangl, S.; Specht, H.M.; Mozes, P.; Jesinghaus, M.; Vordermark, D.; Combs, S.E.; Peltz, F.; Jung, M.P., et al. Correlation of Hsp70 Serum Levels with Gross Tumor Volume and Composition of Lymphocyte Subpopulations in Patients with Squamous Cell and Adeno Non-Small Cell Lung Cancer. Front Immunol 2015, 6, 556, doi:10.3389/fimmu.2015.00556.

58. Chanteloup, G.; Cordonnier, M.; Isambert, N.; Bertaut, A.; Hervieu, A.; Hennequin, A.; Luu, M.; Zanetta, S.; Coudert, B.; Bengrine, L., et al. Monitoring HSP70 exosomes in cancer patients' follow up: a clinical prospective pilot study. J Extracell Vesicles 2020, 9, 1766192, doi:10.1080/20013078.2020.1766192.

59. Cordonnier, M.; Chanteloup, G.; Isambert, N.; Seigneuric, R.; Fumoleau, P.; Garrido, C.; Gobbo, J. Exosomes in cancer theranostic: Diamonds in the rough. Cell Adh Migr 2017, 11, 151-163, doi:10.1080/19336918.2016.1250999.

60. Multhoff, G.; Seier, S.; Stangl, S.; Sievert, W.; Shevtsov, M.; Werner, C.; Pockley, A.G.; Blankenstein, C.; Hildebrandt, M.; Offner, R., et al. Targeted Natural Killer Cell-Based Adoptive Immunotherapy for the Treatment of Patients with NSCLC after Radiochemotherapy: A Randomized Phase II Clinical Trial. Clinical cancer research : an official journal of the American Association for Cancer Research 2020, 26, 5368-5379, doi:10.1158/1078-0432.CCR-20-1141.

61. Tomita, M.; Shimizu, T.; Ayabe, T.; Yonei, A.; Onitsuka, T. Prognostic significance of tumour marker index based on preoperative CEA and CYFRA 21-1 in non-small cell lung cancer. Anticancer Res 2010, 30, 3099-3102. 